\title{
Institutional Isomorphism Revisited: Convergence and Divergence in Institutional Change*
}

\author{
JENS BECKERT \\ Max Planck Institute for the Study of Societies, Cologne
}

\begin{abstract}
Under the influence of groundbreaking work by John Meyer and Brian Rowen, as well as Paul DiMaggio and Walter Powell, over the last 30 years research in the new sociological institutionalism has focused on processes of isomorphism. I argue that this is a one-sided focus that leaves out many insights from other institutional and macrosociological approaches and does not do justice to actual social change because it overlooks the role played by divergent institutional development. While the suggestion of divergent trends is not new, there have been few attempts to integrate divergence into the theoretical premises of the new sociological institutionalism. Based on the typology proposed by DiMaggio and Powell, I show that the mechanisms identified by them as sources of isomorphic change can support processes of divergent change as well. The theoretical challenge is to identify conditions under which these mechanisms push institutional change toward homogenization or divergence.
\end{abstract}

The new sociological institutionalism is the most influential theory in recent decades addressing issues of institutional development (DiMaggio and Powell 1983; Meyer and Rowen 1977). This theoretical approach was developed in connection with the study of organizations (DiMaggio and Powell 1991; Strang and Soule 1998), but has since been expanded to cover the analysis of institutional change more generally, including the analysis of global processes of sociopolitical change (Boyle and Meyer 1998; Meyer et al. 1997; Meyer 2009).

The focus of the new sociological institutionalism is on processes of institutional homogenization rather than on developments leading to institutional divergence: "The traditional emphasis of institutional approaches to organization studies has been on the explanation of organizational similarity based on institutional conditions" (Lawrence and Suddaby 2006:215; see also Tempel and Walgenbach 2005). This emphasis derives in part from the seminal contribution of DiMaggio and Powell (1983). Their paper became one of the most cited articles in sociology ever and together with the article by Meyer and Rowen (1977) shaped subsequent research in the field (Mizruchi and Fein 1999). The DiMaggio and Powell piece focuses on processes of homogenization via the concept of isomorphism. The authors argue that once organizational models are institutionalized, they become diffused, which causes organizational structures to grow more and more alike. ${ }^{1}$

\footnotetext{
*Address correspondence to: Jens Beckert, Max Planck Institute for the Study of Societies, Paulstr. 3, 50676 Köln, Germany. Beckert@mpifg.de. I would like to thank Marie-Laure Djelic, Sigrid Quack, Richard Scott, Wolfgang Streeck, Anne Tempel, Christine Trampusch, and the anonymous reviewers for their very helpful comments.

${ }^{1}$ The emphasis on homogenization also prevails in the article by Meyer and Rowen (1977). Meyer later extended new sociological institutionalism beyond the study of formal organizations to institutional development in general. The "world society" approach (Meyer et al. 1997) emphasizes the dispersion of cognitive scripts that become legitimated as taken-for-granted ways to regulate specific coordination problems. This result increases homogenization of institutional models on a global scale.
} 
The intention of the article by DiMaggio and Powell (1983:147) was not to claim that processes of isomorphism are somehow more important than the opposite, but rather to provide an alternative theoretical explanation for isomorphism. The authors sought to understand it not as the outcome of market-driven rationalization processes - hence the reference to Max Weber in their title-but as rooted in institutional dynamics. Independent of this intention, the influence of the article has led to a one-sided picture of institutional development in the new sociological institutionalism in which isomorphism is given undue analytic weight (Mizruchi and Fein 1999). ${ }^{2}$

Yet, while the new sociological institutionalism developed, other institutional approaches also grew, taking a very different perspective: instead of seeing institutional evolution as converging on one model, they focused on continued and newly emerging institutional divergence. This holds true for work done on the level of macro sociological theory as well as for institutional theories from other disciplines. For example, Eisenstadt (2000) advocates the concept of "multiple modernities," which he developed on the basis of a critical assessment of modernization theory. Eisenstadt explicitly rejects the idea that modern societies merge into one trajectory: "[T]he institutional responses to the problems arising out of growing structural differentiationthe patterns of integration - that emerge in different societies at seemingly similar stages of differentiation may vary considerably across societies" (Eisenstadt 1998:42). Huntington's (1996) catch phrase "the clash of civilizations" emphasizes the cultural differences between "civilizations" and foresees profound conflict over different institutional models of social organization. Comparative institutionalist advances like the "varieties of capitalism" approach (Hall and Soskice 2001), comparative research on business systems (Whitley 1994, 1999), historical institutionalism (Dobbin 1994; Streeck and Thelen 2005; Thelen 1999), comparative cultural sociology (Lamont and Thévenot 2000), and the new economic sociology (Hamilton and Biggart 1992; Guillén 2001) have likewise investigated processes of institutional development from a comparative perspective without proceeding from the assumption of isomorphism.

Notwithstanding the difference that the new sociological institutionalism focuses mostly on organizational fields while the approaches cited above have a broader orientation, the coexistence of both kinds of processes - isomophism and divergence - is puzzling. The question is not whether homogenization or divergence is more important. Empirical studies uncover evidence for both. It is, however, theoretically unsatisfactory to simply accept that these opposing processes are reflected in different theories stating rival trends in social development (Djelic 1998:1). Why is it that institutional theories cannot conceptualize their coexistence?

This article contributes to a more integrated perspective on institutional development. To comprehend processes of institutional homogenization and heterogeneity, one needs to understand the mechanisms underlying the processes by which institutional models prevalent in one social setting (country or organizational field) also emerge in another or not. I argue that the existence of contradictory

\footnotetext{
${ }^{2}$ This holds true even for those approaches that emphasize divergence by introducing concepts like "editing," "bricolage," "translation," or "hybridization" (Campbell 2004; Czarniawska and Sevón 1996; Djelic 2006:73). This is because these concepts also use pressures toward isomorphism as their starting point, which is only qualified in the process of implementation of institutional models. Imitation never leads to an identical copy but to something different. This argument, however, is too defensive because it remains based on the assumption of diffusion of institutional forms.
} 
theories regarding institutional change is not primarily a problem of empirical failure but an issue of theoretical deficiency. Only a theoretical conceptualization able to spell out the conditions under which we can expect either one of the two processes can help to explain the different directions institutional change can take.

To advance such a theoretical conceptualization, I make use of the typology introduced by DiMaggio and Powell (1983). I distinguish four mechanisms that provide explanations for the forces operating behind processes of institutional change. Three of those mechanisms are largely identical to the forms of organizational isomorphism introduced by DiMaggio and Powell (1983). These are power (coercive isomorphism), attraction (normative pressures), and mimesis (mimetic processes). To this I add competition as a fourth mechanism, which was deliberately not discussed by DiMaggio and Powell because they sought to provide an alternative to competition-based explanations of institutional isomorphism (DiMaggio and Powell 1983:147). Contrary to the way these mechanisms have been applied in subsequent research in institutional theory, I show that none are unequivocal regarding the direction of change. All four mechanisms can support processes of institutional homogenization, but under different conditions they can also lead to institutional divergence. This is not to be understood as a critique of the article by DiMaggio and Powell. Instead, I aim to provide a theoretical base from within the theoretical premises of the new sociological institutionalism that shifts the focus away from isomorphism and allows for a more integrated perspective, connecting the literature on organizational fields to the macro-oriented debates cited above.

The illustrations I use to support my argument are taken mostly from debates on the development of political-legal frameworks for states in the context of transnational influences (Boyle and Meyer 1998; Djelic 1998; Djelic and Sahlin-Andersson 2006a; Meyer et al. 1997; Sorge 2005; Westney 1987). An alternative approach would have been to draw illustrations from research on organizations. ${ }^{3}$ The decision not to follow the latter course in no way undermines the applicability of my claims to organizations. There is no evidence that mechanisms of institutional change operate altogether differently in organizational and political-legal fields. This point is also supported by developments within the new sociological institutionalism itself: the theoretical premises claiming a trend toward homogenization have been applied to markets (Baum and Lant 2003) and to political-legal development by the worldsystems approach (Meyer et al. 1997) without important conceptual changes precisely because the logics operating in these realms are not fundamentally different. I chose not to focus on organization because once more macro-oriented institutional changes in the political sphere are made the reference point, the logic of my argument becomes all the more clear.

I present that argument by addressing the four mechanisms separately. In discussing each I first show how the mechanism can support processes of homogenization before demonstrating how it can equally support processes of divergence. The subsequent task emerging from the observation of the indeterminacy of the four mechanisms is to specify the conditions under which they lead development either toward homogenization or in the opposite direction. I offer some thoughts about this in the course of the discussion that are summarized in the conclusion.

\footnotetext{
${ }^{3}$ Some references to organizations are nevertheless provided in the text and especially in the footnotes.
} 


\section{MECHANISMS OF INSTITUTIONAL HOMOGENIZATION AND HETEROGENEITY}

\section{Power}

One mechanism of institutional change identified by DiMaggio and Powell (1983) is coercion. Homogenization "results from both formal and informal pressures exerted on organizations by other organizations upon which they are dependent and by cultural expectations in the society within which organizations function" (DiMaggio and Powell 1983:150). Coercion can be exercised directly but also indirectly by making accessibility to desired resources dependent on compliance. Yet, while scholars from institutional organization theory refer to the formal and informal exertion of pressure as a mechanism leading to institutional homogenization, empirical findings are much more ambiguous with regard to the direction in which power influences institutional development.

On the one hand, research on cross-national institutional convergence does show that isomorphic change occurs if existing institutions have been thoroughly discredited, morally or functionally, and, at the same time, if there is a powerful external actor who is able to enforce a new institutional design. In the case of a severe national or organizational crisis and the presence of a hegemonic power that exercises its influence, it is likely that the new institutional design will correspond to the institutional model of the external power holder since this power holder will perceive his or her native institutional solutions as functionally and morally adequate (superior) without seeing the need for "experimentation." Using the model as a template may also ensure better compatibility between the two institutional systems and thereby facilitate the exercise of domination.

Examples of cross-societal institutional adaptations based on external power exercised over a society are documented particularly in studies of institutional transformation after wars (Djelic 1998; Herrigel 2000). ${ }^{4}$ The victorious countries have the power to dismantle existing institutional forms and impose upon the defeated enemy guidelines for the design of new political institutions and corporate organizational structures. These institutions do not have to be exact copies of the institutions of the victorious power, but they do stand in close affinity to them. The institutions would not have developed indigenously. Examples are the democratic reforms imposed by the United States on Germany and Japan after World War II. In these cases, institutional isomorphism was a reaction to a specific power constellation and to the normative failure of existing institutions. ${ }^{5}$

Isomorphism induced by power must be expected not only when "more powerful societies demand the emulation of organizational forms" (Westney 1987:223), but also as the result of more subtle and indirect processes, such as the extension of the legal regulations that a state is obliged to follow (DiMaggio and Powell 1983:154). In Europe, the latter point is exemplified in the expansion of lawmaking competence from the level of nation states to that of the European Union. A further mechanism has been called "conditionality" (Djelic 2006:70) and refers to policies of international political bodies like the International Monetary Fund, the World Bank, or

\footnotetext{
${ }^{4}$ The references to the cited studies do not imply that the authors of the studies actually hold the position that institutions converge cross-nationally.

${ }^{5}$ Examples from management refer to hostile takeovers where organizational models are forced upon the company bought.
} 
the European Commission to make credits or accession (to the European Union) dependent on specific reforms.

On the other hand, while power has been discussed in sociological institutionalism predominantly as a homogenizing force, this does not hold true unequivocally. The most obvious case is situations in which the power holder has no interest in homogenization despite a unilateral distribution of power. In terms of political regimes, the politics of colonial powers provide examples of this. These regimes developed institutional structures that were distinctively different from those in the "motherland"-for instance, in terms of political rights of the colonial subjects. Here power preserves divergence.

Divergence, despite clear power differentials, can also have its roots in institutional logics. Comparative political economists argue that increasing returns support institutional heterogeneity against isomorphic pressures. Institutions gravitate toward inertia because the existing distribution of resources tends to produce the kind of political decisions that reinforce them. The more entrenched a specific institution is, the more difficult it becomes to dismantle it because the institution distributes power resources in a way that supports its continuity. Consequently, paths once embarked on will not be altered easily, even if powerful interests emerge that intend to change the institution (Arthur 1989; David 1985; Pierson 2000; Thelen 1999). To the extent that societies have entered different paths at points of "critical juncture," the different systems have a great staying power. ${ }^{6}$ Cross-societal institutional heterogeneity remains, since the existing institutional regulation is reinforced by the prevailing institutional logics. Examples for this are continuing cross-national differences between welfare state regimes, systems of professional training, corporate governance (see the contributions in Hall and Soskice 2001; Streeck and Thelen 2005), and distinct approaches in industrial policies (Dobbin 1994). With regard to organizations, a comparable argument has been made by Hannan and Freeman (1984:149ff), who maintain that inertial forces are one reason why organizations find it difficult to adapt to changes in their environments.

Finally, the success of enforced homogenization depends on social structural and informational conditions. The external power holder must have the organizational capacity to make the envisioned model known and needs support from local actors putting the institutional blueprint into practice. The actual diffusion of an institutional form depends on the distribution of information, finding legitimacy for the models, and on social networks (Campbell 2004; Djelic 2006). Hence, continued divergence can be the result of a lack of organizing capacity despite power imbalances. Examples for this are the current attempts of the West to democratize countries in the Middle East after military intervention. Homogenization fails despite a one-sided distribution of power and the clearly stated political will to achieve convergence with the Western political model.

Therefore, power as a mechanism of institutional change is much more ambivalent than assumed by the new sociological institutionalism. While it can lead to homogenization it can also support divergent institutional change. This is the case when the power holder has no interest in aligning the institutions of the political economy

\footnotetext{
${ }^{6}$ Streeck and Thelen (2005:22f) argue that institutional change remains possible despite the vested interests in existing regulations through a mechanism they call "layering." Instead of changing the existing institution, a new layer is added to it that works on a different principle. If this layer grows faster than the old one, this will set in motion a gradual process of institutional change. An example of this is pension systems to which private insurance is added without formally changing the existing system.
} 
of the dominated nation state with its own. It is also the case when the external power holder cannot overcome the self-perpetuating logics of domestic institutional arrangements, either due to their path dependence or because he or she cannot diffuse the models owing to informational, social structural, or cultural constraints. The result will not be the spread of a specific institutional form but rather new models emerging as hybrids (Campbell 2004).

\section{Attraction}

While power is a push factor that imposes specific institutional regulations upon a social group, institutionalization and institutional change can also be the result of the attraction an institutional model holds for institutional entrepreneurs (Beckert 1999; DiMaggio 1988). Isomorphic institutional change occurs if institutional models exist that institutional entrepreneurs actively seek to imitate because they are interpreted as attractive institutional solutions to the problems being faced. In this case, isomorphic change is the result of voluntary imitation and is motivated by the expectation of achieving superior results after existing institutional models are adopted. ${ }^{7}$ Actors are not pushed but pulled toward a specific institutional solution.

Once institutional models are "in the world," institutional entrepreneurs can adopt them and use them as templates for the design of institutional structures in different contexts. One factor contributing to the attraction of institutional imitation is that imitation circumvents at least some of the learning costs associated with the design of new institutional rules. Actors can install institutions that have already been tested and proven to work elsewhere. This is an incentive for organizational or state actors to "shop around" for "best" institutional practices.

Westney's (1987) study on the institutional transformation of Japan during the Meiji period investigates one of the most fascinating historical examples of processes of institutional imitation on the state level. The deliberate emulation of institutional templates from several European states for essential institutions like the army, police, and civil law was partly a consequence of the pressure exerted by foreign nations to make the acceptance of Japan as a sovereign state according to international law dependent on institutional reforms. However, the emulation was also a quite deliberate attempt at reform on the part of indigenous institutional entrepreneurs who were attracted by the idea of creating the institutional foundations for industrialization in Japan and developing the country into a modern state (Westney 1987:3). A second example is that of Eastern European countries that experienced a "revolutionary situation" when the political and economic institutions of state socialism broke down. Reformers, often educated in the West, were attracted to existing templates since prolonged learning periods were perceived to be inadvisable because of the immediate need to find institutional solutions to regulatory problems (Offe 1996:216). In both cases, the institutional solutions that provided models were not only perceived as successful and morally adequate but also reduced the decision load with regard to selecting which institutional design was suitable to fulfill the mission efficiently or effectively. Moreover, institutional imitation allowed for the depoliticization of the

\footnotetext{
${ }^{7}$ The notion that institution building is primarily a process of imitating existing models was introduced by the French sociologist Gabriel Tarde (see Czarniawska 2004; Schmid 2004). For Tarde, imitation is at the same time an innovative process from which new forms emerge because the outcome of copying will never be an identical model.
} 
introduction of new institutions by framing institution building as a technocratic decision to find the "best" solution. ${ }^{8}$

The attraction of institutional models is closely related to socialization processes in professional training and networks (DiMaggio and Powell 1983:152; Djelic 2004; Maman 2006). In professional training, institutional entrepreneurs learn the cognitive and normative frames that shape their perspectives on regulative goals and the likely means to achieve them. Socialization leads to routines and taken-for-granted institutionalized practices. Professional networks help diffuse these standards across national boundaries and thereby contribute to more homogeneous perspectives on regulative problems and appropriate solutions for them. An empirical example of this has been presented by Quack and Djelic (2005) in their research on the introduction of antitrust regulation in Germany. Antitrust regulation was an American legal tradition that had played no role in Germany before World War II. Until 1945, "competition" in German industry was largely organized by cartels. When the American occupation forces wanted to institutionalize antitrust law in Germany, they made use of a small group of marginal German economists of the Freiburg School who opposed cartels and favored competition. Through sponsored training and visits to the United States, economists from this tradition were further socialized into the American antitrust tradition and subsequently brought into responsible positions in the drafting of German antitrust law. Once antitrust law was passed in 1957, a professional community formed around it and exerted influence not only in Germany but also on the European level. This set a process into motion in the European Union that supported the introduction of European antitrust law. Quack and Djelic $(2005: 256)$ show that the emerging professional network helped to diffuse an institutional model across national boundaries by homogenizing cognitive and normative expectations that actors gradually used in addressing regulatory problems. ${ }^{9}$

However, homogenization is only one possible direction of institutional change based on the mechanism of attraction. Though it is an empirical question to what extent national logics can prevail in a period of multiple exposures to "transnational actors," cross-societal institutional divergence finds support in distinct cognitive and normative frames that inform decisionmakers on "how" to resolve a problem and attract them to distinct solutions. Moreover, the mutual interdependencies between institutions attract institutional entrepreneurs to distinct regulatory solutions that will maintain institutional complementarities, that is, institutional solutions that fit with other institutional regulations prevailing in the specific setting.

The pressures to continue transnational divergence based on the attraction of national institutional rules can be caused by evaluative differences. What is considered by actors to be a rational institutional form, in the sense that it best serves their particularistic material or ideal interests or the functional fulfillment of a task set for the institution, depends on available "repertoires of evaluation" (Lamont and Thévenot 2000). Hence, the attraction of institutional models differs according to the distinct interests, norms, and perceptions of means-ends relationships. Actors perceive problems and possible institutional solutions to them within specific frames that embody

\footnotetext{
${ }^{8}$ In business the imitation of organizational structures and models of business strategies expressed in institutionalized rules has itself become an institutionalized management technique known as "benchmarking" or "best practice." Based on the systematic observation of competitors and the identification of best practices of industry leaders, companies imitate the rules to which the competitor's success is attributed (Camp 1989). Contrary to power-induced isomorphism, benchmarking actively seeks possibilities for the imitation of the rules and practices of other companies to improve performance.

${ }^{9}$ See also the example provided by Djelic (2004), who shows the significance of social networks for the modernization of the French economy after World War II based on American business concepts. Djelic emphasises the co-constitution of networks and institutions.
} 
a shared cultural understanding and provide "strategies of action" (Swidler 1986). These frames are expressed as particular regulatory styles. Consequently, actors with distinctly different backgrounds feel attracted to different institutional models, and the attraction of institutional models differs among actors despite overarching similarities in the situations they confront.

In his study on 19th-century railway policy in France, Britain, and the United States, Dobbin (1994) has shown that, despite very similar starting conditions, distinct organizational models developed in the railway industry because policymakers sought institutional solutions based on distinct national regulatory styles. "[P]olicies in different countries follow fundamentally different logics" (Dobbin 1994:11) because they correspond to different national templates. These cognitive frames will, if organized as national frames, contribute to continuing cross-societal differences in institutional structures. ${ }^{10}$

A further explanation as to why actors feel attracted to different institutions is provided in the varieties-of-capitalism approach by the notion of institutional complementarities (Hall and Soskice 2001:17ff; Höpner 2005). Institutions can fulfill their tasks well only when they are surrounded by other institutions that complement them. It is therefore imprudent to import an institution from another institutional environment if it does not fit into the indigenous institutional set. An example is the way the organization of seemingly unrelated fields of coordination in companies, such as employment protection, stock market capitalization, and employee training systems, tend to correlate. These fields have interrelations that must be taken into account in institutional reforms, which makes certain institutional regulations more attractive than others, depending on the type of economy in which the institutional change is to be introduced.

The mechanism of attraction will lead to isomorphic institutional change in situations where actors from different locations or fields feel pulled toward the same institutional models. This can be expected if external models are perceived as adequate or superior solutions to the regulatory problems to be resolved or if there are transnational professional communities that share similar cognitive and normative frames. Heterogeneity will be reinforced if different institutional models prove attractive because an existing model is evaluated in different ways or because institutional entrepreneurs perceive structures as not fitting together.

\section{Mimesis}

A third mechanism that has been identified by institutional organization theory to explain isomorphic institutional change is mimesis (DiMaggio and Powell 1983:151). Mimesis is similar to the mechanism of attraction in the sense that actors are pulled toward existing institutional models. It differs, however, in not being based on complex processes of mediation through socialization and professional networks. Instead, it is a much simpler form of imitation through which actors react to uncertainty with regard to the effects of institutional rules. In a complex environment in which institutional effects can only be determined ex post, institutional entrepreneurs are not able to identify optimal institutional solutions. If effects cannot be rationally anticipated, the imitation of institutional templates legitimated in the institutional field

\footnotetext{
${ }^{10}$ They may, however, contribute to institutional isomorphism within a society or an organizational field if "strong isomorphic pulls... within the society... outweigh the pulls across societies" (Westney 1987:223).
} 
"compensates" for the lack of rationality of the decision and, moreover, becomes a protective shield for the institutional entrepreneur in case of failure. He or she has done "what others would have done" in that position. Imitation is motivated by disorientation rather than by conviction that the model to be imitated is superior. Since rational assessments for the best institutional design are unavailable, the success of institutions operating elsewhere provides legitimation for using them as templates.

Mimetic isomorphism as a response to uncertainty has been extensively explored by scholars working in the tradition of institutional organization theory (DiMaggio and Powell 1983:155; Frumkin and Galaskiewicz 2004; Kalev et al. 2006; Meyer and Jepperson 2000; Meyer and Rowen 1977; Mizruchi and Fein 1999; Powell and DiMaggio 1991). Findings show that the driving force behind mimetic isomorphism is the legitimation that an institutional regulation finds within an organizational field. An example is the emulation of "zero tolerance" strategies for fighting crime in American cities since they were first put into practice in New York during the 1990s even though no causal relationship between these policies and the reduction of crime rates can be established (Harcourt and Ludwig 2005; Lewitt 2004). Politicallegal regulation can also follow this logic. An example is the intensive observation of labor market reforms in the Netherlands and in Denmark by politicians from other European countries during the 1990s. The labor market success in these two countries legitimated the reforms as successful models suitable for other countries to copy, despite widely different circumstances and uncertain causal relations (Trampusch 2000).

A special case of mimetic isomorphism can be observed in situations where institutional entrepreneurs strategically want to downplay their role in the design of institutional regulation. This can be expected if a proposed institutional design could be seen as serving the interests of the institutional designer in a partisan way. "Distraction from authorship" becomes desirable not as a precaution against the consequences of possible institutional failure, but to guard against the delegitimization of institutional rules due to the suspicion that the institutional design primarily serves the partisan interest of the designers. ${ }^{11}$ Offe (1996:210ff) has analyzed this case for the transition countries in Eastern Europe during the early 1990s. Politicians portrayed the proposed institutional models not as their own creations but either as imitations of institutions from their own society's distant but glorious past or as models based on an institutional template from another country that enjoyed high prestige because of its values and its functional record. That way, politicians could argue that the proposed institutional solution was in the best interest of society at large or that it reconfirmed a celebrated national identity, thus allaying suspicions that the institutions might be designed in the interest of a particular group in society.

This powerful theoretical train of thought explaining institutional homogenization as a response to uncertainty and the need for legitimation has been expanded in the world-society approach from the level of organizational fields to a cognitively oriented cultural theory on the institutional convergence of nation states. Meyer et al. (1997) argue that many of the institutional features of the contemporary nation state "derive from worldwide models constructed and propagated through global cultural

\footnotetext{
${ }^{11}$ In his legal philosophy (\$273), Hegel formulated a similar thought with reference to the constitution: "But it is strictly essential that the constitution, though it is begotten in time, should not be contemplated as made. It is rather to be thought of as above and beyond what is made, as self-begotten and self-centred, as divine and perpetual" (Hegel [1821] 1996:281).
} 
and associational processes" (p. 144f). Cultural models provide global templates for processes of institution building, leading to increasing similarities despite the uncertainties surrounding their efficacy. The theory of "world society" emphasizes the dispersion of cognitive scripts that become legitimate as the taken-for-granted way to regulate a specific coordination problem, leading to increasingly similar formal structures and rule systems.

Like the other mechanisms discussed, however, mimesis caused by uncertainty does not unequivocally point toward institutional homogenization. Institutional divergence will prevail if institutional templates observed elsewhere are not considered legitimate institutional solutions.

The imitation of institutional templates will provide legitimation only if the imitated institutions are perceived as instrumentally successful and as consistent with espoused value orientations. Which institutional models provide legitimation to institutional entrepreneurs depends on cultural identities as well as political and economic interests. The objection to an institutional model practiced somewhere else can be a means to define and reinforce a perceived cultural identity by keeping out institutional models that are seen as alien to it.

One example of this is the hostile reaction of German lawmakers in the early 20th century to proposals to introduce an estate tax based on the British model (Beckert 2008:220ff). ${ }^{12}$ Opposition was not founded on functional reasoning regarding the fiscal or economic effects of such an estate tax but on denunciation of this model as culturally alien and therefore unsuitable for Germany. Current political discourses on a putative "European Social Model" also indicate the role of cultural identities in the legitimation of institutions that contribute to persistent differences between institutional models of welfare states despite similar functional challenges. While Anglo-Saxon countries introduced welfare-to-work-policies in the 1990s, "French policymakers consider the British model unacceptable and the American model outright cruel" (Kahl 2007:3). Islamic countries that oppose the importation of specific institutions from the West-like formal schooling and professional training for girls refer explicitly to categorizations that see these institutions as contradicting Islamic values. For religious reasons, institutional templates encounter resistance, which leads to maintained or reinforced divergence. The importance of cultural legitimation as a possible barrier against institutional convergence found greatest attention in Huntington's (1996) diagnosis of increased intersocietal cultural conflicts.

While the legitimation of specific institutional models can be a driving force behind processes of institutional homogenization despite unknown or contested functional consequences, the mechanism in itself can lead to both homogenizing and divergent institutional change. Which direction the institutional change takes depends on the condition of legitimation. Do institutional entrepreneurs and those subject to institutional regulations view the model as a legitimate way to resolve the regulatory problem or as an unwanted intrusion into their established interests and identity? The answer to this question depends on culturally anchored worldviews or political rivalries.

\footnotetext{
${ }^{12}$ The examples provided here do not all fulfill the condition that optimal institutional solutions are uncertain. They might simply be espoused or resisted due to wanted or unwanted consequences. The examples show, however, the crucial role played by the legitimation of institutional models as a central condition for mimesis.
} 


\section{Competition}

The three mechanisms of institutional change discussed so far all reflect, in a modified way, the mechanisms of institutional isomorphism introduced by DiMaggio and Powell (1983). These scholars deliberately left competition out of their seminal article because they were aiming for a theoretical conceptualization of isomorphism that would provide an alternative to Max Weber's emphasis on the role of competitive market pressures in explaining processes of bureaucratization (DiMaggio and Powell 1983:147f). That there are alternatives to efficiency-based explanations of institutional homogenization, however, does not mean that competition is not also a force exerting pressure for institutional change. Indeed, many theories in the social sciences pay special attention to it, and empirical evidence confirms the relevance of this mechanism.

Theories referring to competition as a mechanism of homogenization assume that competitive pressure leads to the institutional convergence of organizations or institutional models of nation states because inefficient institutional solutions are eliminated. Neoclassical economic theory expects competitive pressure, under conditions of perfect markets, to lead to convergence on an "optimal" production function. Given the asymmetric distribution of information and transaction costs - as assumed by transaction-cost economics - the economy will include hierarchies and networks. Their shape, however, will be determined by the need to reduce transaction costs (Williamson 1985, 1994), and companies will converge on an optimal institutional structure that minimizes such costs.

The assumption of institutional isomorphism due to competition presupposes the effective operation of evolutionary selection processes. Alternatively, it must be assumed that actors can unequivocally identify the cost structures of different institutional designs and are able to install efficient institutions despite collective-action problems and possible political or cultural resistance to these "optimal" models. ${ }^{13}$ On the level of firms competition creates homogenizing pressures especially if companies have highly standardized products and cannot shield themselves from cost-based competition through strategies of product differentiation (Chamberlin 1933). On the level of political-legal institutions, competition can cause isomorphic pressure if one assumes that countries compete with each other in providing favorable institutional conditions for globally mobile businesses. In order to attract production facilities, the imitation of "efficient" tax laws, labor laws, or environmental standards can be credited to the mechanism of competition. Under conditions of globalization and liberalization, this "regulatory competition" between states has become a central feature of political economies, with the possible effect of increasing institutional homogenization. Frequently, this homogenization is seen as a "race to the bottom."

Like the other three mechanisms, however, competition is ambivalent in its effects on the direction of institutional change. A long-standing argument in the social sciences is that competition supports the development of diverse political-legal rules and organizational models that allow for niches in which nation states and companies specialize.

In classical sociological theories influenced by Charles Darwin's theory of evolution, the suggestion already figures prominently that increasing divergence, not

\footnotetext{
${ }^{13}$ Adherents of institutional organization theory in particular have rejected this claim. In contrast, population ecologists (Hannan and Freeman 1989) assume the existence of an evolutionary selection process fitting organizational structures to environmental conditions.
} 
homogenization, is to be expected from competition. Herbert Spencer and the early works of Durkheim ([1893] 1984), in particular, were influenced by this traditional line of argument. In economics, Ricardo's ([1823] 2006) theory of comparative advantages assumes cross-national divergence based on different factor endowments of national economies. The overall argument for institutional divergence due to competitive pressure is that competition pushes firms (or countries) to specialize, to create niches for themselves, and that these niches are supported by distinct institutional regulations. In market sociology, Harrison White $(1981,2002)$ took up Edward Chamberlin's insight on competition through the creation of product differentiation. White's W(y)-model is based on the assumption that producers reciprocally observe each other - they take each other into account. The result of these mutual observations, however, is not that they try to imitate each other and ultimately converge on one product. Instead, they attempt to specialize, to occupy a niche for themselves not occupied by a competitor, and thereby create product heterogeneity in the market. Ronald Burt (1992) applied network analytic reasoning to the heterogeneity of organizational forms in a market. He investigated the relationship between the network structure of firms in a market and the observable organizational heterogeneity. Burt argues that markets in which firms have greater structural autonomy maintain higher levels of organizational heterogeneity because structurally autonomous firms "can be less nervous about reorganizing to try alternative organization forms" (Burt 1983:195). Hence, it is not competition as such that leads to heterogeneity; instead, heterogeneity is a function of the network structure of the market.

Comparative political economy also provides arguments explaining why competition may reinforce differences in the institutional structure of the economy. ${ }^{14}$ The "varieties of capitalism" approach (Hall and Soskice 2001) distinguishes between two types of capitalism. Competition enables the stable reproduction of these diverse regimes because each has comparative institutional advantages for the production of specific goods and services. ${ }^{15}$ The profitability derived from the respective institutional regulations and the interconnectedness of regulations due to institutional complementarities shield the existing types from cross-societal homogenization. In a similar vein, Guillén (2001:6ff) argues in a comparative study on organizational change in companies that the increasing mutual awareness of companies in a globalizing economy does not lead to the imitation of one model, but rather to processes in which organizational models and heterogeneous regulatory regimes undergo differentiation because firms and countries are equipped to do different things and must therefore capitalize on "their indigenous sources of strength" (Guillén 2001:13). Even where countries follow policies of market-oriented reforms, they differ substantially in the ways in which they adopt neoliberal institutional structures (Guillén et al. 2005). Concepts can be "interpreted and utilized differently against the background of nationally distinct forms of business systems" (Tempel and Walgenbach 2005:11).

Streeck (2005) has taken this argument further. By designing institutional regulations that are uniquely attractive for a particular sector of the economy, a region or state can carve out a niche in which specialized companies can gain a superior competitive position: "Different sectors require different physical supports and

\footnotetext{
${ }^{14}$ The business-systems approach (Whitley 1999) is similar in its emphasis of national differences despite the increasing globalization of competition.

${ }^{15}$ This point, however, is empirically controversial. Developments in coordinated market economies indicate, for instance, substantial changes in the system of corporate governance (Höpner 2003). This may be a sign for increasing adaptation of coordinated market economies to the model of liberal market economies.
} 
educational systems, different suppliers and cooperative arrangements, and different rules" (Streeck 2005:12). This assertion is based on the experience of the economic success of small countries (like the Netherlands), which concentrate on one economic sector (in the Dutch case, the transportation industry) by way of institutional regulations that provide an especially attractive institutional environment for companies in this industry.

Just like the other mechanisms discussed, competition can operate in both directions. Competition can even cause convergence and divergence simultaneously. It may force states to change their institutional structures in parallel ways to become more attractive to capital investments, but this may be achieved through specialization in "institutional niches," which, in turn, results in increased heterogeneity (Streeck 2005:16). The direction of institutional change evidently cannot be predicted without knowing what types of differentiation are possible. Pressures to homogenize can be expected under conditions of undifferentiated competition focusing primarily on costs. Yet the more differentiated the global economy is in terms of its product types (sectors), and the more differentiated product markets are, and the greater the structural autonomy of firms in markets is, the less likely it will be that competitive forces will direct organizations toward homogenization. ${ }^{16}$

\section{CONCLUSION}

In this article I scrutinized claims regarding the direction of institutional change based on the three mechanisms invoked in sociological institutionalism to explain institutional homogenization. In addition, the mechanism of competition was discussed. The examination of the four mechanisms shows that none of them has the effect of causing institutional change to head in one direction only. Research in the tradition of the new sociological institutionalism does not do justice to this basic theoretical indeterminacy because it focuses its attention one-sidedly on processes of isomorphism and convergence (Lawrence and Suddaby 2006:215; Tempel and Walgenbach 2005:2). This one-sidedness cannot be justified with reference to the influential work by DiMaggio and Powell (1983), since the authors of this article had as their specific goal to provide an alternative explanation of processes of homogenization - an alternative to Max Weber's claim that the dominance of bureaucratic forms in modern capitalism (which is a homogenizing process) is primarily market driven. Sociological research using the categories introduced by DiMaggio and Powell (1983) took up the notions of coercive isomorphism, mimetic processes, and normative pressures, investigating empirical cases of isomorphic change (Mizruchi and Fein 1999). Studies that focus on deviations from institutional models by highlighting the innovations created in the process of "translation" do not counterbalance this focus on homogenization, since they follow the assumption of institutional diffusion and locate the sources of heterogeneity primarily in the implementation process.

Largely detached from the new sociological institutionalism, other approaches have developed in the social sciences that emphasize institutional heterogeneity. The varieties of capitalism approach, the business systems approach, and historical institutionalism proceed by asking why national institutional differences prevail in

\footnotetext{
${ }^{16}$ Djelic and Sahlin-Anderson (2006b:394) make an important distinction between surface dynamics and background stability by arguing that the "surface level is dense but increasingly powerfully set and embedded in, constrained and directed by, homogenizing meta-rules of the game." Whether this is truly the case is ultimately an empirical question. One can also establish the opposite claim, namely, that many of the processes of institutional homogenization achieved through transnationalization are ceremonial and do not touch more than the surface of social interaction in organizations or political economies.
} 
the organization of the economy. Theories of competition and cultural theories of long-term institutional development also emphasize the durability of institutional differences. Institutional structures are considered to reproduce rather steadily despite global integration. This forms a counterpoint to the new sociological institutionalism but leads to a research program that is eventually just as one-sided. Not surprisingly, one important criticism of the comparative capitalism literature is directed against its static perspective (Callaghan 2007; Jackson and Deeg 2006; Streeck 2001), which does not pay sufficient attention to homogenizing change. Similar criticisms have been launched against comparative cultural approaches.

Undoubtedly, there are powerful influences directing institutional change toward greater homogeneity. In the contemporary world of globalization and transnationalization this should be expected, and the deliberate attempt by organizations and states to emulate existing institutional templates gives significant empirical support to this claim. However, it is equally true that institutional heterogeneity is continuously reproduced. This should motivate scholars to develop theoretical models that allow for the simultaneity of these two countervailing processes (see also Campbell 2004:83).

The challenge arising from assessment of the four mechanisms I have offered here is to identify the conditions under which the mechanisms steer institutions in either one of the two directions. I have indicated some of these conditions in the text. Strong exogenous powers, perceived functional or normative attraction of institutional models, cognitive and normative congruencies among institutional entrepreneurs across national boundaries, the legitimation of institutional models among stakeholders, and direct competitive pressures in undifferentiated markets are conditions favorable to institutional homogenization. On the other side, the prevalence of powerful defenders of indigenous institutional rules, incongruent cognitive and normative frames of actors in different national settings, institutional complementarities, the interest of power holders in institutional differences, the lack of legitimacy for specific institutional models and sector-specific demands, as well as differentiated products and the structural autonomy of firms are conditions favorable to divergence.

Admittedly, these conditions are still relatively vague. To make them more precise, further empirical research is needed. Contrary to studies in the new sociological institutionalism this research must not be set up to look for empirical proof for tendencies of homogenization (or heterogeneity), but must rather ask much more openly which of these two tendencies is observed, and due to which causal mechanism it prevails.

This article contributes to the development of a theoretical framework that allows for such an open perspective. In so doing, it expresses skepticism toward a long tradition in the social sciences claiming that "social change towards modernity in different societies will take place in a rather uniform and linear way" (Knöbl 2003:97), with societies eventually merging into one trajectory. This claim is wrong, insofar as the conditions under which mechanisms of institutional change operate do not always work in favor of homogenization. Not only does the "iron cage" have other causes than those envisioned by Max Weber; it may not exist at all.

\section{REFERENCES}

Arthur, Brian W. 1989. "Competing Technologies, Increasing Returns, and Lock-In by Historical Events." Economic Journal 99:116-31. 
Baum, Joel A. C., and Theresa K. Lant. 2003. "Hits and Misses: Managers' (Mis)categorization of Competitors in the Manhattan Hotel Industry." Pp. 118-55 in Geography and Strategy: Advances in Strategic Management, edited by J. A. C. Baum and O. Sorenson. Oxford, UK: JAI Press/Elsevier.

Beckert, Jens. 1999. "Agency, Entrepreneurs and Institutional Change: The Role of Strategic Choice and Institutionalized Practices in Organizations.” Organization Studies 20:777-99.

. 2008. Inherited Wealth. Princeton, NJ: Princeton University Press.

Boyle, Elizabeth H. and John W. Meyer. 1998. "Modern Law as Secularized and Gobal Model: Implications for the Sociology of Law." Soziale Welt 49:113-32.

Burt, Ronald S. 1983. Corporate Profits and Cooptation. New York: Academic Press.

- 1992. Structural Holes. The Social Structure of Competition. Cambridge, MA: Harvard University Press.

Callaghan, Helen. 2007. Convergence? Divergence? Hybridization? How Transnational Law-Making Affects the Clash of Capitalisms. Manuscript, European University Institute, Florence, Italy.

Camp, Robert C. 1989. Benchmarking: The Search for Industry Best Practices that Lead to Superior Performance. Milwaukee, WI: Quality Press.

Campbell, John L. 2004. Institutional Change and Globalization. Princeton, NJ: Princeton University Press.

Chamberlin, Edward. 1933. The Theory of Monopolistic Competition. Cambridge, UK: Cambridge University Press.

Czarniawska, Barbara. 2004. "Gabriel Tarde and Big City Management." Distinktion 9:119-33.

Czarniawska, Barbara and Guje Sevón, eds. 1996. Translating Organizational Change. Berlin, Germany: de Gruyter.

David, Paul. 1985. "Clio and the Economics of QWERTY." American Economic Review 75:332-37.

DiMaggio, Paul J. 1988. "Interest and Agency in Institutional Theory." Pp 3-21 in Institutional Patterns and Organizations: Culture and Environment, edited by L. G. Zucker. Cambridge, MA: Ballinger Pub.

DiMaggio, Paul J. and Walter W. Powell. 1983. "The Iron Cage Revisited: Institutional Isomorphism and Collective Rationality in Organizational Fields.” American Sociological Review 48:147-60.

- eds. 1991. The New Institutionalism in Organizational Analysis. Chicago, IL: University of Chicago Press.

Djelic, Marie-Laure. 1998. Exporting the American Model. The Postwar Transformation of European Business. Oxford, UK: Oxford University Press.

. 2004. "Social Networks and Country-to-Country Transfer: Dense and Weak Ties in the Diffusion of Knowledge." Socio-Economic Review 2:341-70.

2006. "Marketization: From Intellectual Agenda to Global Policy-Making." Pp. 53-73 in Transnational Governance. Institutional Dynamics of Regulation, edited by M. Djelic and K. Sahlin-Andersson. Cambridge, UK: Cambridge University Press.

Djelic, Marie-Laure and Kerstin Sahlin-Andersson, eds. 2006a. Transnational Governance: Institutional Dynamics of Regulation. Cambridge, UK: Cambridge University Press.

- 2006b. "Institutional Dynamics in a Re-Ordering World." Pp. 375-97 in Transnational Governance. Institutional Dynamics of Regulation. Cambridge, MA: Cambridge University Press.

Dobbin, Frank. 1994. Forging Industrial Policy. The United States, Britain and France in the Railway Age. Cambridge, UK: Cambridge University Press.

Durkheim, Emile. [1893] 1984. The Division of Labor in Society. New York: Free Press.

Eisenstadt, Samuel N. 1998. "Comparative Studies and Sociological Theory: Autobiographical Notes." American Sociologist 29:38-58. 2000. "Multiple Modernities." Daedalus 129:1-29.

Frumkin, Peter and Joseph Galaskiewicz. 2004. "Institutional Isomorphism and Public Sector Organization." Journal of Public Administration Research and Theory 14:283-307.

Guillén, Mauro F. 2001. The Limits of Convergence. Globalization and Organizational Change in Argentina, South Korea, and Spain. Princeton, NJ: Princeton University Press.

Guillén, Mauro F., W. J. Henisz, and B. A. Zelner. 2005. "The Worldwide Diffusion of Market-Oriented Infrastructure Reform, 1997-1999." American Sociological Review 70:871-97.

Hall, Peter A. and David Soskice. 2001. "An Introduction to Varieties of Capitalism." Pp. 1-44 in Varieties of Capitalism. The Institutional Foundations of Comparative Advantage, edited by P. A. Hall and D. Soskice. Oxford, UK: Oxford University Press.

Hamilton, Gary and Nicole Biggart. 1992. "Market, Culture, and Authority: A Comparative Analysis of Management and Organization in the Far East." Pp. 181-221 in The Sociology of Economic Life, edited by M. Granovetter and R. Swedberg. Boulder, CA: Westview.

Hannan, Michael and John Freeman. 1984. "Structural Inertia and Organizational Change." American Sociological Review 49:149-64. 
1989. Organizational Ecology. Cambridge, MA: Harvard University Press.

Harcourt, Bernard E. and Jens Ludwig. 2005. "Broken Windows: New Evidence from New York City and a Five-City Social Experiment." Chicago Univ. Public Law and Legal Theory Working Paper No.93.

Hegel, Georg W. F. [1821] 1996. Philosophy of Right, translated by S. W. Dyde. New York: Prometheus Books.

Herrigel, Gary. 2000. "American Occupation, Market Order, and Democracy: Reconfiguring the Steel Industry in Japan and Germany after the Second World War." Pp. 340-99 in Americanization and Its Limits: Remaking US Technology and Management in Postwar Europe and Japan, edited by J. Zeitlin and G. Herrigel. New York: Oxford University Press.

Höpner, Martin. 2003. Wer beherrscht die Unternehmen? Shareholder-Value, Managerherrschaft und Mitbestimmung in Deutschland. Frankfurt a.M., Germany: Campus.

- 2005. "What Connects Industrial Relations and Corporate Governance?" Socio-Economic Review 3:331-59.

Huntington, Samuel P. 1996. The Clash of Civilizations and the Remaking of World Order. New York: Simon \& Schuster.

Jackson, Gregory and Richard Deeg. 2006. How Many Varieties of Capitalism? Comparing the Comparative Institutional Analyses of Capitalist Diversity. MPIfG Discussion Paper 06/2. Köln, Germany: MaxPlanck-Institut für Gesellschaftsforschung.

Kahl, Sigrun. 2007. No title. Paper for the Max Planck Summer Conference on Economy and Society, Schloss Ringberg, Germany, July 18-21, 2007.

Kalev, Alexandra, Frank Dobbin, and Erin Kelly. 2006. "Best Practices or Best Guesses? Diversity Management and the Remediation of Inequality." American Sociological Review 71:589-917.

Knöbl, Wolfgang. 2003. "Theories that Won't Pass Away: The Never Ending Story of Modernization Theory." Pp. 96-107 in Handbook of Historical Sociology, edited by G. Delanty. London, UK: Sage.

Lamont, Michèle and Laurent Thévenot. 2000. "Introduction: Toward a Renewed Comparative Cultural Sociology.” Pp. 1-22 in Rethinking Comparative Cultural Sociology. Repertoires of Evaluation in France and the United States, edited by M. Lamont and L. Thévenot, Cambridge, UK: Cambridge University Press.

Lawrence, Thomas B. and Roy Suddaby. 2006. "Institutions and Institutional Work." Pp. 215-54 in Handbook of Organization Studies, edited by S. Clegg et al. London, UK: Sage.

Lewitt, Steven D. 2004. "Understanding Why Crime Fell in the 1990s: Four Factors that Explain the Decline and Six that Do Not." Journal of Economic Perspectives 18:163-190.

Maman, Daniel. 2006. "Diffusion and Translation: Business Groups in the New Israeli Corporate Law." Sociological Perspectives 49:115-35.

Meyer, John W. 2009. World Society. Oxford, UK: Oxford University Press.

Meyer, John W., John Boli, George M. Thomas and Francisco O. Ramirez. 1997. "World Society and the Nation-State." American Journal of Sociology 103:144-81.

Meyer, John W. and Ronald Jepperson. 2000. "The 'Actors' of Modern Society: The Cultural Construction of Social Agency." Sociological Theory 18:100-20.

Meyer, J. W. and Brian Rowen. 1977. "Institutionalized Organizations: Formal Structure as Myth and Ceremony." American Journal of Sociology 83:340-63.

Mizruchi, Mark S. and Lisa C. Fein. 1999. "The Social Construction of Organizational Knowledge: A Study of the Uses of Coercive, Mimetic, and Normative Isomorphism." Administrative Science Quarterly 44:653-83.

Offe, Claus. 1996. "Designing Institutions in East European Transitions." Pp. 199-226 in The Theory of Institutional Design, edited by R. E. Goodin. Cambridge, UK: Cambridge University Press.

Pierson, Paul. 2000. "Increasing Returns, Path Dependence, and the Study of Politics." American Political Science Review 94:251-67.

Powell, Walter W. and Paul J. DiMaggio. 1991. "Introduction." Pp. 1-38 in The New Institutionalism in Organizational Analysis, edited by W. W. Powell and P. J. DiMaggio. Chicago, IL: University of Chicago Press.

Quack, Sigrid and Marie-Laure Djelic. 2005. "Adaptation, Recombination, and Reinforcement: The Story of Antitrust and Competition Law in Germany and Europe." Pp. 255-81 in Beyond Continuity. Institutional Change in Advanced Political Economies, edited by W. Streeck and K. Thelen. Oxford, UK: Oxford University Press.

Ricardo, David. [1823] 2006. Principles of Political Economy and Taxation. New York: Cosimo Classics.

Schmid, Hans-Bernhard. 2004. "Evolution by Imitation. Gabriel Tarde and the Limits of Memetics." Distinktion 9:103-18.

Sorge, Arndt. 2005. The Global and the Local. Understanding the Dialectics of Business Systems. Oxford, UK: Oxford University Press. 
Strang, David and Sarah A. Soule. 1998. "Diffusion in Organizations and Social Movements: From Hybrid Corn to Poison Pills." Annual Review of Sociology 24:265-90.

Streeck, Wolfgang. 2001. "Introduction: Explorations into the Origins of Nonliberal Capitalism in Germany and Japan." Pp. 1-38 in The Origins of Nonliberal Capitalism, edited by W. Streeck and K. Yamamura. Ithaca, NY: Cornell University Press.

2005. National Politics in a Global Economy: Reinventing the Political? Unpublished manuscript.

Streeck, Wolfgang and Kathleen Thelen. 2005. "Introduction." Pp. 1-39 in Beyond Continuity. Institutional Change in Advanced Political Economies, edited by W. Streeck and K. Thelen. Oxford, UK: Oxford University Press.

Swidler, Ann. 1986. "Culture in Action: Symbols and Strategies.” American Sociological Review 51:273-86.

Tempel, Anne and Peter Walgenbach. 2005. Global Standardization of Organizational Forms and Management Practices? What New Institutionalism and the Business-Systems Approach Can Learn from Each Other. Manuscript, University of Erfurt, Germany.

Thelen, Kathleen. 1999. "Historical Institutionalism in Comparative Politics." Annual Review of Political Science 2:369-404.

Trampusch, Christine. 2000. "Grenzen der Diffusion. Die formative Phase der Arbeitsmarktpolitik in den Niederlanden.” Pp. 153-77 in Sozialmodell Europa. Konturen eines Phänomens, Jahrbuch für Europaund Nordamerikastudien 4/2000, edited by A. Aust, S. Leitner, and S. Lessenich. Opladen, Germany: Leske+Budrich.

Westney, Eleanor D. 1987. Imitation and Innovation. The Transfer of Western Organizational Patterns to Meiji Japan. Cambridge, MA: Harvard University Press.

White, Harrison. 1981. "Where Do Markets Come From?” American Journal of Sociology 87:517-47. 2002. Markets from Networks. Princeton, NJ: Princeton University Press.

Whitley, Richard, ed. 1994. European Business Systems. Firms and Markets in Their National Contexts. London, UK: Sage Publications.

1999. Divergent Capitalisms: The Social Structuring and Change of Business Systems. Oxford, UK: Oxford University Press.

Williamson, Oliver. 1985. The Economic Institutions of Capitalism. New York: Free Press.

- 1994. "Transaction Cost Economics and Organization Theory." Pp. 77-107 in The Handbook of Economic Sociology, edited by N. J. Smelser and R. Swedberg. Princeton, NJ: Princeton University Press. 